\title{
Development of Plant-Parasitic Nematode Populations on Forage Crops under Field Conditions
}

\author{
Mahfouz M.M. Abd-Elgawad*, Mohamed F.M. Eissa*, Abd-Elmoneim Y. El- \\ Gindi** and Grover C. Smart*** \\ * Phytopathology Department, National Research Centre; \\ ** Department of Agricultural Zoology and Nematology, Faculty of Agriculture, University of Cairo, \\ Giza, Egypt; \\ *** Department of Entomology and Nematology, IFAS, University of Florida, USA.
}

\begin{abstract}
The continuous increase in cost and scarcity of mineral fertilizers resulting from the use of high-cost energy sources has renewed interests in organic recycling and biological nitrogen-fixation to improve soil fertility and productivity. Forage legumes can fix nitrogen from atmosphere which has the merit to offer nitrogen for both crop production and soil fertility. However, plant-parasitic nematodes (PPNs) interactions with leguminous crops can be agronomically damaging under various conditions. The present study examined population development of each of the PPN genera Meloidogyne spp., Paratrichodorus spp., Criconemella spp., Pratylenchus spp., Tylenchorhynchus, and Tylenchus spp. on fourteen legume cultivars (i.e. 'Florida' red clover, 'Nolin' red clover, 'Kenland' red clover, 'Kenstar' red clover, 'Tibbee' crimson clover, 'Dixie' crimson clover, 'Mt. Barker' Subterranean clover, 'Amclo' arrowleaf clover, 'FL - 77' alfalfa, 'Abon' persian clover, 'Wood ford' big flower vetch, 'Seqrest' ball clover, 'Kondinin' rose clover, and 'Chief' crimson clover). The nematode initial and final populations varied considerably among the legume cultivars. Therefore, we adjusted for the rate of nematode multiplication by using analysis of covariance. However, we could not use one of the statistical multiple comparison methods because each treatment had different mean of squares for the experimental error. Consequently, a matrix was designed to test the significance of nematode populations on the cultivars using the t-test. Using a computer program, the exact (numerical) level of statistical significance for nematode densities among the cultivars could be established. Relatively lower populations of the nematode genera were found on 'FL-77' alfalfa plants.
\end{abstract}

Key words: analysis of covariance, forage legumes, nematode population development.

\section{Introduction}

Many legumes rank high among other forage crops as they offer the best quality feed for livestock since they are palatable, help maintain proper functioning 
of the ruminant digestive processes and stimulate high production of both meat and milk. Also, they are used as green manure by ploughing them into the soil. Forage legumes contain symbiotic bacteria called rhizobia within nodules in their root systems, producing nitrogen compounds that help the plant to grow and compete with other plants. When the plant dies, the fixed nitrogen is released, making it available to other plants; this helps to fertilize the soil. Therefore, in many traditional and organic farming practices, fields are rotated through various types of crops, which usually include one consisting mainly or entirely of clover, often referred to as green manure. Eventually, in view of the continuing increase in cost and scarcity of mineral fertilizers resulting from the use of high-cost fossil and renewed energy, there is renewed interest in organic recycling and biological nitrogen-fixation to improve soil fertility and productivity. Clearly, forage legumes can fix nitrogen from atmosphere which has the merit to offer nitrogen for both crop production and soil fertility.

The efficiency of nitrogen fixation by these symbiotic bacteria is dependent on many factors, including the legume, air, soil conditions and soil microorganisms. Among biotic factors, the absence of the required rhizobia species constitutes the major constraint in the nitrogen fixation process. Plant-parasitic nematodes (PPNs) are also considered among other limiting factors since these parasites have been reported to interfere with nodule formation, development, and functions (Taha et al., 1974). Clearly, many forage legumes are very susceptible to damage by plant parasitic nematodes, especially the root-knot nematodes (Meloidogyne spp.) which are endoparasitic forms capable of reproducing not only on forage crops but also on a wide variety of host plants (Abd-Elgawad and Askary, 2015). From an agronomic perspective, the interactions of PPNs with leguminous crops can be devastating (e.g., Allison, 1956; Baxter and Gibson, 1958; Baltensperger et al., 1985a and b; Barker, 1998; Davis and Mitchum, 2005).

The objective of this study was to determine the population development of plant-parasitic nematodes on very common cultivars of forage crops grown in Florida, USA. Taking into consideration the aggregated distribution usually shaping the nematode patterns, we adjusted also for the error resulting from this uneven distribution via the use of analysis of covariance.

\section{Materials and Methods}

The experiment was established at the main Agronomy Farm, Gainesville, Florida, USA. Each plot measured $2.1 \times 6.1 \mathrm{~m}(7 \times 20 \mathrm{ft})$ with each forage legume cultivar and the fallow control replicated four times. The soil type is Arredondo fine sand. The plots had been planted to pigeon pea, Cajanus cajan, for eight months and then left fallow for four months before the experiment was established. Soil samples were taken twice, the first time when the plants were still in the seedling stage (January, 1984) and the second time at the first harvest of the foliage (April, 
1984). Nematodes were extracted from $100 \mathrm{~cm}^{3}$ soil from each sample using a centrifugal-flotation technique (Caveness and Jensen, 1955), placed in vials, and stored in a refrigerator at $4{ }^{\circ} \mathrm{C}$ for no more than three days until identified to genera and counted. Data were analyzed by analysis of covariance. Initial populations of nematodes were plotted as covariates with their final populations as dependent variables for the analysis of covariance. As treatments (the cultivars) were found to have different mean of squares for the experimental error, a matrix was designed to test the statistical significance of nematode populations on these cultivars using the t-test. Using a computer program (ACOVS), the exact probability level of significance for nematode densities among the cultivars could be established.

\section{Results}

Differences in the initial population levels of plant-parasitic nematodes $\left(P_{i}\right)$ among tested legume cultivars resulted in differences in their final populations $\left(P_{f}\right)$ for these cultivars. However, since there was a regression relationship $(P=0.0001)$ between the $P_{i}$ and the $P_{f}$; the $P_{f}$ was adjusted using analysis of covarinace to make the $P_{f}$ the best estimate of what it would have been if the $P_{i}$ had been the same for each genus of nematodes (Table 1). Consequently, the adjusted means of nematode populations for each genus were significantly different $(P \leq 0.05)$ on various planted cultivars, i.e., the cultivars had an effect on nematode populations as indicated by the adjusted populations of nematodes in Table (1). This statistical analysis was applied separately for Meloidogyne spp., using square root transformation, and for Paratrichodorus spp. Populations of each other nematode genera, Criconemella spp., Tylenchorhynchus spp., Tylenchus spp. and Pratylenchus spp., were too low to be treated statistically. Therefore, these genera were combined and analyzed statistically as one group (Table 1). A matrix of 14 rows representing the tested cultivars was designed to test for significance of nematode population levels between plant cultivars (Tables 2-4). Relatively lower population densities were found on 'FL-77' alfalfa. Most of the tested legume cultivars had non-significant difference between them for nematode reproduction at $P \leq 0.05$, e.g. 'Florida' red clover and 'Nolin' red clover $(P=0.66)$ for Meloidogyne spp. (Table 2); 'Dixie' crimson clover and 'Wood ford' big flower vetch $(P=0.99)$ for Paratrichodorus spp. (Tables 3), and 'Tibbee' crimson clover and 'Chief' crimson clover $(P=0.86)$ for the total populations of Criconemella spp., Pratylenchus spp., Tylenchorhynchus spp. and Tylenchus spp. (Table 4). However, differences in the readiness of some legume cultivars for nematode reproduction were so great that the significant levels were less than 0.01 ; e.g. 'Kenstar' red clover and 'Tibbee' crimson clover $(P=0.007)$ for Meloidogyne spp. (Table 2); 'Abon' persian clover and 'Chief' crimson clover $(P=0.003)$ for Paratrichodorus spp. (Table 3 ); and 'Kenland' red clover and 'Kenstar' red clover $(P=0.0006)$ for the total populations of Criconemella spp., Tylenchorhynchus spp. and Tylenchus spp. (Table 4). 
Table (1): Genera and means of adjusted ${ }^{+}$final populations of nematodes on forage legume cultivars.

\begin{tabular}{|c|c|c|c|}
\hline Legume (cultivar) & 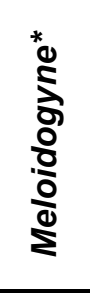 & 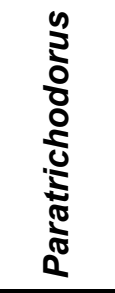 & 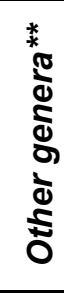 \\
\hline 'Florida' Red Clover & 9.5 & 53.0 & 40 \\
\hline 'Nolin' Red Clover & 8.6 & 110.3 & 80 \\
\hline 'Kenland' Red Clover & 8.1 & 71.0 & 0 \\
\hline 'Kenstar' Red Clover & 5.2 & 109.6 & 70 \\
\hline 'Tibbee' Crimson Clover & 11.4 & 46.0 & 31 \\
\hline 'Dixie' Crimson Clover & 11.3 & 58.2 & 73 \\
\hline 'Mt. Barker' Subterranean Clover & 5.5 & 60.0 & 88 \\
\hline 'Amclo' Arrowleaf Clover & 8.0 & 45.0 & 54 \\
\hline 'FL - 77' Alfalfa & 3.6 & 48.7 & 14 \\
\hline 'Abon' Persian Clover & 7.4 & 33.5 & 26 \\
\hline 'Wood ford' Big flower vetch & 10.2 & 57.9 & 48 \\
\hline 'Seqrest' Ball Clover & 6.6 & 91.1 & 47. \\
\hline 'Kondinin' Rose Clover & 6.3 & 95.9 & 58 \\
\hline 'Chief' Crimson Clover & 6.1 & 117.1 & 27 \\
\hline
\end{tabular}

+ Nematode genera per $100 \mathrm{~cm}^{3}$ soil. The adjustment was based on analysis of covariance, using the initial nematode populations as covariates and their final populations as dependent variables since there was regression relationship between them $(P=0.0001)$.

* Square root transformation was used for the original mean numbers of Meloidogyne.

** The populations included the total nematodes of Criconemella, Tylenchorhynchus, Tylenchus and Pratylenchus. 
Table (2): Matrix table of statistical probability levels to compare populations of Meloidogyne spp. on fourteen* cultivars of forage legumes.

\begin{tabular}{lccccccccccccccc}
\hline $\begin{array}{l}\text { Cultivar } \\
\text { number }\end{array}$ & $\mathbf{1}$ & $\mathbf{2}$ & $\mathbf{3}$ & $\mathbf{4}$ & $\mathbf{5}$ & $\mathbf{6}$ & $\mathbf{7}$ & $\mathbf{8}$ & $\mathbf{9}$ & $\mathbf{1 0}$ & $\mathbf{1 1}$ & $\mathbf{1 2}$ & $\mathbf{1 3}$ & $\mathbf{1 4}$ \\
\hline 1 & 0 & 0.6546 & 0.5471 & 0.0516 & 0.3782 & 0.4051 & 0.0686 & 0.0674 & 0.0098 & 0.3256 & 0.7653 & 0.1873 & 0.1454 & 0.1169 \\
2 & 0.6546 & 0 & 0.8426 & 0.1246 & 0.1862 & 0.2047 & 0.1642 & 0.4042 & 0.0271 & 0.5896 & 0.4572 & 0.2792 & 0.2076 & 0.2565 \\
3 & 0.5471 & 0.8424 & 0 & 0.2555 & 0.1420 & 0.1826 & 0.2845 & 0.0758 & 0.0619 & 0.7659 & 0.3571 & 0.3434 & 0.4561 & 0.3307 \\
4 & 0.0518 & 0.1290 & 0.2335 & 0 & 0.0065 & 0.0069 & 0.8957 & 0.2992 & 0.4642 & 0.3195 & 0.0282 & 0.5117 & 0.6071 & 0.8928 \\
5 & 0.3782 & 0.1862 & 0.1429 & 0.0065 & 0 & 0.9542 & 0.0092 & 0.4202 & 0.0008 & 0.0673 & 0.5545 & 0.0321 & 0.0228 & 0.0167 \\
6 & 0.4051 & 0.1642 & 0.2845 & 0.0059 & 0.9542 & 0 & 0.0097 & 0.4310 & 0.0099 & 0.0739 & 0.6005 & 0.0349 & 0.0252 & 0.0193 \\
7 & 0.0686 & 0.8042 & 0.9759 & 0.8967 & 0.0092 & 0.0097 & 0 & 0.2489 & 0.3894 & 0.3365 & 0.0384 & 0.5999 & 0.7014 & 0.7916 \\
8 & 0.4874 & 0.0271 & 0.8619 & 0.2002 & 0.1202 & 0.1310 & 0.2489 & 0 & 0.0477 & 0.7700 & 0.3258 & 0.5266 & 0.4377 & 0.3720 \\
9 & 0.0090 & 0.6896 & 0.7659 & 0.4642 & 0.0008 & 0.0009 & 0.3894 & 0.0477 & 0 & 0.0881 & 0.9042 & 0.1688 & 0.2154 & 0.2614 \\
10 & 0.3256 & 0.4572 & 0.3571 & 0.3195 & 0.0873 & 0.0739 & 0.3865 & 0.7700 & 0.0891 & 0 & 0.2055 & 0.7311 & 0.6271 & 0.5460 \\
11 & 0.7653 & 0.3702 & 0.5434 & 0.0282 & 0.5545 & 0.6005 & 0.0384 & 0.3258 & 0.0042 & 0.2055 & 0 & 0.1118 & 0.0839 & 0.0647 \\
12 & 0.1873 & 0.8076 & 0.4581 & 0.5117 & 0.0321 & 0.0349 & 0.5990 & 0.5256 & 0.1688 & 0.7311 & 0.1118 & 0 & 0.8866 & 0.7939 \\
13 & 0.1454 & 0.2535 & 0.3897 & 0.6071 & 0.0229 & 0.0252 & 0.7014 & 0.4377 & 0.2154 & 0.6271 & 0.0838 & 0.8866 & 0 \\
14 & 0.1169 & & & 0.6928 & 0.0167 & 0.0193 & 0.7916 & 0.8720 & 0.2614 & 0.5460 & 0.0647 & 0.7039 & 0.9053 & 0 \\
\hline
\end{tabular}

* The fourteen cultivars as numbered in the matrix are as follows; $1=$ 'Florida' red clover, $2=$ 'Nolin' red clover, $3=$ 'Kenland' red clover, $4=$ 'Kenstar' red clover, $5=$ 'Tibbee' crimson clover, 6 = 'Dixie' crimson clover, $7=$ 'Mt. Barker' Subterranean clover, $8=$ 'Amclo' arrowleaf clover, $9=$ 'FL -77 ' alfalfa, $10=$ 'Abon' persian clover, $11=$ 'Wood ford' big flower vetch, $12=$ 'Seqrest' ball clover, $13=$ 'Kondinin' rose clover, and $14=$ 'Chief' crimson clover. 
Table (3): Matrix table of statistical probability levels to compare populations of Paratrichodorus spp. on fourteen* forage legume cultivars.

\begin{tabular}{|c|c|c|c|c|c|c|c|c|c|c|c|c|c|c|}
\hline $\begin{array}{l}\text { Cultivar } \\
\text { number }\end{array}$ & 1 & 2 & 3 & 4 & 5 & 6 & 7 & 8 & 9 & 10 & 11 & 12 & 13 & 14 \\
\hline 1 & 0 & 0.0343 & 0.5078 & 0.0374 & 0.7986 & 0.8537 & 0.7942 & 0.7782 & 0.8758 & 0.4992 & 0.8607 & 0.1781 & 0.1294 & 0.0224 \\
\hline 2 & 0.0343 & 0 & 0.1489 & 0.9700 & 0.9223 & 0.0681 & 0.0653 & 0.0250 & 0.0274 & 0.0098 & 0.0641 & 0.4877 & 0.5941 & 0.8916 \\
\hline 3 & 0.5078 & 0.1489 & 0 & 0.1499 & 0.3464 & 0.6328 & 0.6781 & 0.3342 & 0.4009 & 0.1684 & 0.6833 & 0.4608 & 0.3461 & 0.0852 \\
\hline 4 & 0.0374 & 0.9790 & 0.1499 & 0 & 0.0214 & 0.0653 & 0.0661 & 0.0230 & 0.0287 & 0.0086 & 0.0619 & 0.4041 & 0.6065 & 0.7786 \\
\hline 5 & 0.7986 & $\begin{array}{l}0.0223 \\
0.0681\end{array}$ & 0.3464 & 0.0214 & 0 & 0.6441 & 0.5961 & 0.9687 & 0.9168 & 0.6379 & 0.6515 & 0.0830 & 0.0636 & 0.0096 \\
\hline 6 & 0.9527 & 0.0653 & 0.6328 & 0.0652 & 0.6441 & 0 & 0.9462 & 0.6149 & 0.7208 & 0.3601 & 0.9908 & 0.2167 & 0.1606 & 0.0312 \\
\hline 7 & 0.7942 & 0.0250 & 0.6781 & 0.0661 & 0.5961 & 0.9462 & 0 & 0.5764 & 0.6692 & 0.3293 & 0.9365 & 0.2474 & 0.1783 & 0.0351 \\
\hline 8 & 0.7782 & 0.0274 & & 0.0230 & 0.9687 & 0.6149 & 0.5764 & 0 & 0.8868 & 0.6626 & 0.6225 & 0.0861 & 0.0614 & 0.0095 \\
\hline 9 & 0.8758 & 0.0098 & 0.4009 & 0.0267 & 0.9168 & 0.7209 & 0.6692 & 0.8868 & 0 & 0.5680 & 0.7288 & 0.1186 & 0.9788 & 0.0125 \\
\hline 10 & 0.4992 & 0.0641 & & 0.0086 & 0.6379 & 0.3501 & 0.3293 & 0.6626 & 0.5689 & 0 & 0.3579 & 0.9341 & 0.0238 & 0.0031 \\
\hline 11 & 0.8607 & 0.4877 & 0.6233 & 0.0619 & 0.6515 & 0.9908 & 0.9369 & 0.6236 & 0.7235 & 0.3570 & 0 & 0.2123 & 0.1559 & 0.0298 \\
\hline 12 & 0.1781 & 0.5941 & & 0.4941 & 0.0980 & 0.2167 & 0.2474 & 0.0861 & 0.1186 & 0.0341 & 0.2123 & 0 & 0.8546 & 0.2275 \\
\hline 13 & 0.1204 & 0.8916 & 0.3461 & 0.6065 & 0.0636 & 0.1606 & 0.1783 & 0.0614 & 0.0788 & 0.9238 & 0.1869 & 0.8546 & 0 & 0.4222 \\
\hline 14 & 0.2224 & & 0.0852 & 0.7786 & 0.0096 & 0.0312 & 0.0351 & 0.0095 & 0.0125 & 0.0031 & 0.9228 & 0.3275 & 0.4222 & 0 \\
\hline
\end{tabular}

* The fourteen cultivars as numbered in the matrix are as follows; $1=$ 'Florida' red clover, 2 = 'Nolin' red clover, $3=$ 'Kenland' red clover, $4=$ 'Kenstar' red clover, $5=$ 'Tibbee' crimson clover, 6 = 'Dixie' crimson clover, 7 = 'Mt. Barker' Subterranean clover, 8 = 'Amclo' arrowleaf clover, $9=$ 'FL -77 ' alfalfa, I0 = 'Abon' persian clover, 11 = 'Wood ford' big flower vetch, 12 = 'Seqrest' ball clover, 13 = 'Kondinin' rose clover, and 14 = 'Chief' crimson clover. 
Table (4): Matrix table of statistical probability levels to compare nematode populations* on fourteen** ${ }^{*}$ ltivars of forage legumes.

\begin{tabular}{|c|c|c|c|c|c|c|c|c|c|c|c|c|c|c|}
\hline $\begin{array}{l}\text { Cultivar } \\
\text { number }\end{array}$ & 1 & 2 & 3 & 4 & 5 & 6 & 7 & 8 & 9 & 10 & 11 & 12 & 13 & 14 \\
\hline 1 & 0 & 0.0671 & 0.0269 & 0.1662 & 0.6789 & 0.1298 & 0.0300 & 0.5080 & 0.2437 & 0.5424 & 0.6976 & 0.3325 & 0.2883 & 0.5632 \\
\hline 2 & 0.0671 & 0 & 0.0202 & 0.6230 & 0.0277 & 0.7367 & 0.7251 & 0.2387 & 0.0045 & 0.0194 & 0.1511 & 0.1373 & 0.3111 & 0.0223 \\
\hline 3 & 0.0269 & 0.0002 & 0 & 0.0006 & 0.0680 & 0.0004 & 0.0001 & 0.0053 & 0.2813 & 0.1965 & 0.0110 & 0.0123 & 0.0031 & 0.1046 \\
\hline 4 & 0.1662 & 0.6330 & 0.0006 & 0 & 0.0757 & 0.8863 & 0.8063 & 0.4677 & 0.0137 & 0.0522 & 0.3201 & 0.2065 & 0.5526 & 0.0577 \\
\hline 5 & 0.6789 & 0.0277 & 0.0680 & 0.0757 & 0 & 0.0576 & 0.0111 & 0.2836 & 0.4433 & 0.6405 & 0.4232 & 0.9816 & 0.2106 & 0.8621 \\
\hline 6 & 0.1294 & 0.7367 & 0.0004 & 0.0863 & 0.0576 & 0 & 0.4925 & 0.3906 & 0.0103 & 0.0405 & 0.2620 & 0.2413 & 0.4881 & 0.0455 \\
\hline 7 & 0.0300 & $\begin{array}{l}0.7251 \\
02387\end{array}$ & 0.0001 & 0.4068 & 0.0111 & 0.4925 & 0 & 0.1251 & 0.0015 & 0.0072 & 0.0733 & 0.0658 & 0.1719 & 0.0083 \\
\hline 8 & 0.5080 & 0.0045 & & 0.4677 & 0.2836 & 0.3906 & 0.1251 & 0 & 0.0695 & 0.2042 & 0.7829 & 0.6452 & 0.0984 & 0.2182 \\
\hline 9 & 0.2427 & 0.0194 & & 0.0137 & 0.4433 & 0.0193 & 0.0015 & 0.0695 & 0 & 0.5792 & 0.1292 & 0.1519 & 0.0475 & 0.5536 \\
\hline 10 & 0.5424 & 0.1511 & & 0.0522 & 0.8405 & 0.0405 & 0.0072 & 0.2042 & 0.5702 & 0 & 0.0166 & 0.3599 & 0.1887 & 0.9789 \\
\hline 11 & 0.6576 & 0.1371 & & 0.3201 & 0.4232 & 0.2620 & 0.0733 & 0.4829 & 0.1202 & 0.3166 & 0 & 0.9696 & 0.6440 & 0.3305 \\
\hline 12 & 0.7339 & 0.3111 & & 0.2965 & 0.4516 & 0.2413 & 0.0658 & 0.8453 & 0.1319 & 0.3400 & 0.0606 & 0 & 0.6128 & 0.3561 \\
\hline 13 & 0.3983 & 0.0222 & 0.0031 & 0.8826 & 0.2106 & 0.4921 & 0.1419 & 0.8554 & 0.0578 & 0.1497 & 0.6499 & 0.6128 & 0 & 0.1597 \\
\hline 14 & 0.6632 & & 0.1046 & 0.0577 & 0.0621 & 0.0455 & 0.0096 & 0.8152 & 0.5536 & 0.9789 & 0.3209 & 0.3861 & 0.1597 & 0 \\
\hline
\end{tabular}

* The nematode populations included the total individuals of Criconemella, Tylenchorhynchus, Tylenchus and Pratylenchus.

** The fourteen cultivars as numbered in the matrix are as follows; 1 = 'Florida' red clover, 2 = 'Nolin' red clover, $3=$ 'Kenland' red clover, $4=$ 'Kenstar' red clover, $5=$ 'Tibbee' crimson clover, 6 = 'Dixie' crimson clover, 7 = 'Mt. Barker' Subterranean clover, 8 = 'Amclo' arrowleaf clover, $9=$ 'FL - 77' alfalfa, I0 = 'Abon' persian clover, 11 = 'Wood ford' big flower vetch, 12 = 'Seqrest' ball clover, 13 = 'Kondinin' rose clover, and 14 = 'Chief' crimson clover. 


\section{Discussion}

Data on nematode populations on the legume cultivars supported the phenomenon of uneven distribution of nematodes in the field as previously reported (Goodell and Ferris, 1980; Abd-Elgawad, 1992, 2016; Abd-Elgawad and Hasabo, 1995; Been and Schomaker, 2013). Using analysis of covariance, we adjusted for the error resulting from uneven distribution. Seinhorst (1967) stated that some authors consider the rate of multiplication as the only important parameter $\left(P_{f}=a P_{i}\right)$ where $P_{i}$ and $P_{f}$ are initial and final nematode densities, respectively and $a$ is the rate of nematode multiplication. Seinhorst (1970) noted that those authors seem to be unaware of the possibility that the value of a may not be independent of $\mathrm{P}_{\mathrm{i}}$. Therefore, we adjusted for the rate of multiplication by using analysis of covariance. However, we could not use one of the multiple comparison methods because each treatment had different mean of squares for the experimental error. Consequently, a matrix was designed to test the significance of nematode populations on the cultivars using the t-test. Using a computer program, the exact level of significance for nematode densities among the cultivars could be established (Tables 2-4).

Data showed that 'FL-77' alfalfa had relatively higher levels of nematode resistance than did the other cultivars and so it could be used perhaps to incorporate resistance into other varieties either by hybridization or by recurrent selection within alfalfa populations. This cultivar may be better adapted to Meloidogyne spp.-infested soils than the other studied forage legumes. Since the tested cultivars differed as hosts for nematode development, additional genetic material should be examined to search for higher levels of resistance. Therefore, Hamdi (1982) and Quesenberry et al. (2014) recommended further promotion of research, development, application and dissemination of information available on various aspects of biological nitrogen-fixation, including symbiotic systems of rhizobia/legume and Azolla/blue-green algae, and free-living nitrogen-fixing bacteria and blue-green algae. The latter authors presented prospects for continued genetic improvement in resistance for Meloidogyne spp. using conventional and modern molecular methods.

\section{Acknowledgement}

This study was supported in part by the NRC In-house project entitled 'Pesticide alternatives against soilborne pathogens attacking legume cultivation in Egypt'.

\section{References}

Abd-Elgawad, M.M.M. (1992). Spatial distribution of the phytonematode community in Egyptian citrus groves. Revue De Nematologie 15: 367-373. 
Abd-Elgawad, M.M.M. (2016). Use of Taylor's Power Law parameters in Nematode Sampling. International Journal of PharmTech Research 9(12): 999-1004.

Abd-Elgawad, M.M. and Hasabo, S.A. (1995). Spatial distribution of the phytonematode community in Egyptian berseem clover fields. Fundamental and Applied Nematology 18(4): 329-334.

Abd-Elgawad, M.M.M. and Askary, T.H. (2015). Impact of phytonematodes on agriculture economy. In: Askary, T.H. and Martinelli, P.R.P. (eds) Biocontrol Agents of Phytonematodes. Wallingford, CAB International, UK, pp. 3-49.

Allison, J.L. (1956). Root knot of perennial forage legumes. Phytopathology 46: 6.

Baltensperger, D.D., Quesenberry, K.H., Homer, E.S., Dunn, R.A. and AbdElgawad, M.M. (1985a). Interaction of alfalfa recurrent phenotypic selection cycles with root-knot nematodes. Soil and Crop Science Society of Florida Proceedings. 44, 162-164.

Baltensperger, D. D., Quesenberry, K. H., Dunn, R. A. and Abd-Elgawad, M. M. (1985b). Root-knot nematode interaction with berseem clover and other temperate forage legumes. Crop Science 25, 848-851.

Barker K. (1998). Introduction and synopsis of advancements in nematology. In: Barker, K.R., Pederson, G.A. and Windham, G.L. (eds), Plant Nematode Interactions. American Society of Agronomy, Crop Science Society of America, Soil Science Society of America, Madison, WI, pp 1-20.

Baxter, L.W. and Gibson, P.B. (1958). Root-knot nematodes cause injury to white clover. South Carolina Agric. Exper. Sta. Ann. Rep. 70: 29-30.

Been, T.H. and Schomaker, C.H. (2013). Distribution patterns and sampling. In: Perry, R.N. and Moens, M. (Eds). Plant Nematology, 2nd Edition. Wallingford, UK, CABI Publishing, pp. 331-358.

Caveness, F.E and Jensen, H.J. (1955). Modification of the centrifugal-flotation technique for the isolation and concentration of nematodes and their eggs in soil. Proceedings of the Helminthological Society of Washington 22: 8789.

Davis, E.L. and Mitchum, M.G. (2005). Nematodes. Sophisticated parasites of legumes. Plant Physiology 137(4):1182-1188. doi: 10.1104/pp.104.054973

Goodell, P. and Ferris, H. (1980). Plant-parasitic nematode distribution in an alfalfa field. Journal of Nematology 12: 136-141.

Hamdi, Y.A. (1982). Application of nitrogen-fixing systems in soil improvement and management. In: FAO Soils Bulletin no. 49 / Rome (Italy), FAO, 193 pp. 
Quesenberry, K.H., Munoz, P., Blount, A., Kenworthy, K. and Crow, W. (2014). Breeding forages in Florida for resistance to nematodes. Crop and Pasture Science 65(11) 1192-1198 https://doi.org/10.1071/CP13437

Seinhorst, J.W. (1967). The relationship between population increase and population density in plant-parasitic nematodes. II. Sedentary nematodes. Nemalologica 13: 157-171.

Seinhorst, J.W. (1970). Dynamics of populations of plant parasitic nematodes. Annual Review of Phytopathology 8: 131-156.

Taha, A.H.Y., Yousif, G.M. and El-Hadidy, T.T. (1974). Interaction of root-knot nematode infection and symbiotic nitrogen fixation in leguminous hosts. Annals of Agricultural Sciences, Faculty of Agriculture, Ain Shams University 19(1): 33-38. 


\section{الملخص العربي}

\section{تطور النيماتودا المتطفلة نباتيا على محاصيل العلف في الحقل}

محفوظ محمد مصطفى عبد الجواد*؛ محمد فهمي محمد عيسي*؛ عبد المنعم ياسين الجندي* وجروفر سمارت****

$$
\begin{aligned}
& \text { * قسم أمراض النبات - المركز القومي للبحوث - الدقي Y Y Y Y I - القاهرة - مصر. } \\
& \text { ** قسم الحيوان والنيماتولجيا الزراعية - كلية الزراعة - جامعة القاهرة - القاهرة - مصر. }
\end{aligned}
$$

**** قسم الحشرات والنيماتولجي - معهد علوم الغذاء والزراعة - جامعة فلوريدا - الولايات المتحدة الأمريكية.

لقد أدت الزيادة المستمرة في تكلفة وندرة الأسمدة المعدنية الناتجة عن استخدام مصادر

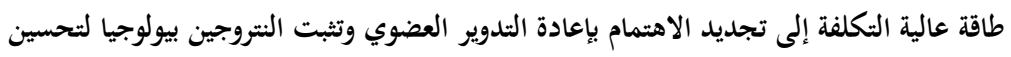

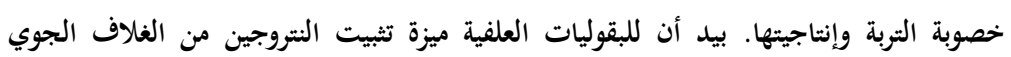

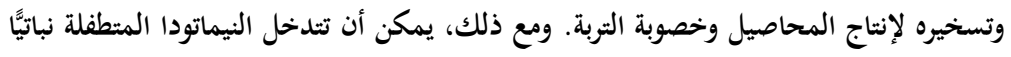

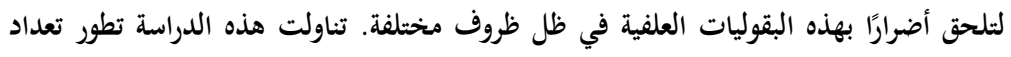

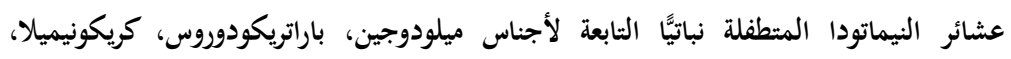

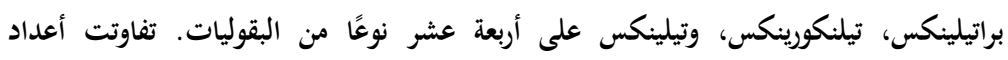

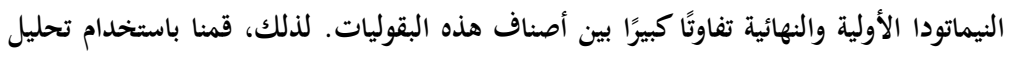

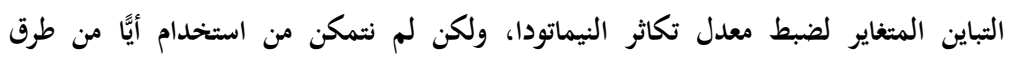

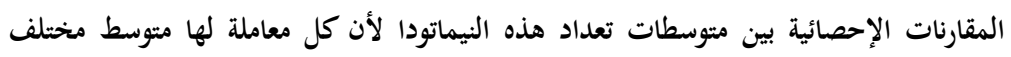
خاص بمربع الخطأ التجريبي. بناء على ذلك، تم تصميم مصفوفة لكل مجتمع نيماتودي لتحديد

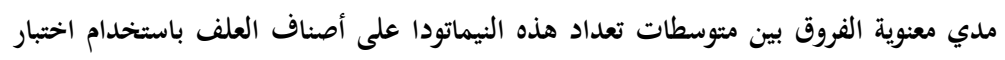

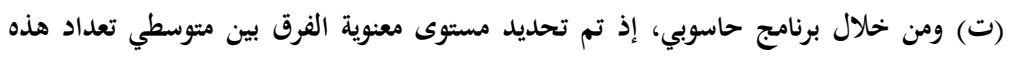

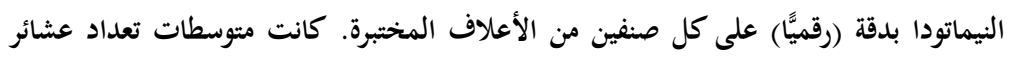

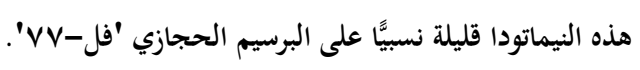
الكلمات الدالة: تحليل التباين المتغاير، البقوليات العلفية، تطور عشائر النيماتودا. 